The study of fly ash filler behaviour in the polymer matrix of polyethyleneterephthalate

${ }^{1}$ Ketegenov T., ${ }^{1}$ Khan N.*, ${ }^{2}$ Tyumentseva 0. ${ }^{1}$ Karagulanova $\mathrm{A}$

${ }^{1}$ Al-Farabi Kazakh National University, Almaty, Kazakhstan

${ }^{2}$ Institute of Combustion Problems, Almaty Kazakhstan

*E-mail: natasha.khan.v@gmail.com
The purpose of the investigation was to study the behavior of mechanically activated fly ash filler containing carbon in a polymer matrix of polyethylene terephthalate (PET). By means of the methods of optical and electron microscopy the change of physical and chemical properties of fly ash after intensive grinding in planetary mills of centrifugal type was considered. The research showed that mechanically activated filler, in contrast to its non-activated analog, structures the polymer matrix and provides improving the characteristics of the composite material.

Keywords: fly ash; mechanical activation; filler; a polymer composition.
Механикалық белсендірілген ұшпа күлді полиэтилентерефталат полимерлі матрицасында толтырғыш ретінде қолдануды зерттеу

${ }^{1}$ Кетегенов Т., ${ }^{1}$ Хан Н.*, ${ }^{2}$ Тюменцева О., ${ }^{1}$ Карагуланова A.

1Әл-Фараби атындағы Қазақ ұлттық университеті, Алматы, Қазақстан ${ }^{2}$ Жану проблемалары институты, Алматы, Қазақстан

*E-mail: natasha.khan.v@gmail.com
Зерттеу мақсаты - полиэтилентерефталатты полимерлі матрицасында көміртегі бар, механикалық белсендірілген ұшпа күл толтырғышының қасиетін зерттеу. Оптикалық және электронды микроскопия әдістері көмегімен центрден тепкіш күш типтес планетарлы диірмендерде қарқынды ұсақтаудан кейінгі ұшпа күлдің физикахимиялық қасиеттері зерттелінді. Сонымен қатар, ұшқыш күлдің осындай механикалық өңдеуден кейін полиэтилентерефталатты полимерлі маптериалдарға толтырғыш ретінде қолданылу мүмкіндігі қарастырылды. Механикалық өңделген және өңделмеген күлді толтырғыштары бар полимерлі материалдардың механикалық беріктігі, суды сіңіру қабілеті және қышқылға төзімділігі зерттелініп, салыстырмалы талдау жасалынды. Зерттеулер нәтижесінде механикалық белсендірілген толтырғыш белсендірілмеген аналогымен салыстырғанда полимерлі матрицанының құрылымын түзіп, композиционды материалдың сипаттамаларын жақсартқанын көрсетті.

Түйін сөздер: ұшпа күл; механикалық белсендіру; толтырғыш; полимерлі материалдар.

\section{Исследование применения механически активированной золы уноса в качестве наполнителя в полимерной матрице полиэтилентерефталата}

${ }^{1}$ Кетегенов Т., ${ }^{1}$ Хан Н.*, ${ }^{2}$ Тюменцева О., ${ }^{1}$ Карагуланова A.

${ }^{1}$ Казахский национальный университет имени аль-Фараби, Алматы, Казахстан ${ }^{2}$ Институт проблем горения Алматы, Казахстан

*E-mail: natasha.khan.v@gmail.com
Целью исследования было изучение поведения механически активированного наполнителя золы-уноса, содержащего углерод, в полимерной матрице из полиэтилентерефталата (ПЭТФ). С помощью методов оптической и электронной микроскопии рассматривалось изменение физико-химических свойств золы-уноса после интенсивного измельчения на планетарных мельницах центробежного типа, а также возможность использования летучей золы после такой механической обработки в качестве наполнителя для полимерного материала, представленного полиэтилентерефталатом. Были изучены и сопоставлены механическая прочность, водопоглощение и кислотостойкость полимерных материалов, наполненных механически обработанным и необработанным зольными наполнителями. Исследования показали, что механически активированный наполнитель, в отличие от его неактивированного аналога, структурирует полимерную матрицу и обеспечивает улучшение характеристик композиционного материала.

Ключевые слова: зола уноса; механическая активация; наполнитель; полимерные материалы. 


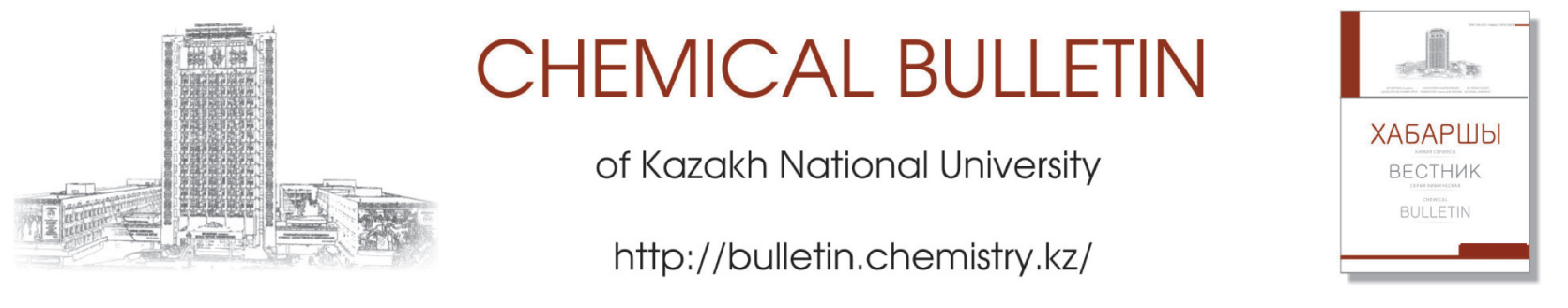

http://doi.org/10.15328/cb1018

\title{
The study of fly ash filler behaviour in the polymer matrix of polyethyleneterephthalate
}

\author{
${ }^{1}$ Ketegenov T., ${ }^{1}$ Khan N.*, ${ }^{2}$ Tyumentseva O., ${ }^{1}$ Karagulanova A. \\ ${ }^{1}$ Al-Farabi Kazakh National University, Almaty, Kazakhstan \\ ${ }^{2}$ Institute of Combustion Problems, Almaty Kazakhstan \\ *E-mail: natasha.khan.v@gmail.com
}

\section{Introduction}

In recent years, polymer-based compositions have found wide application in various branches of industrial and civil construction; it makes high demands on both the performance characteristics and the decorative properties of the polymer material. Generally, the properties of polymers depend not only on the properties of the polymer matrix but also on the properties of the filler. Nowadays, there are lots of fillers that provide the required properties of the composite. In addition to well-known various minerals such as gypsum, talc and carbonates $[1,2]$ for a long time the household waste, such as eggshells [3-6], rice husks [7], coconut husks [8]) and as well the industrial wastes, ash and slag of energy enterprises [9-13], sawdust and wastes from pulp mills $[14,15,16]$, etc. are used as fillers. In this case application of fly ash as filler is beneficial not only from the economic site but also from the environmental perspective due to the reduction of the man-caused environmental load [17].

However, the amount of the utilized ash is much less than the number of its producers, which is associated with high content of harmful compounds including unburned carbon in fly ash composition. This fact limits the applications of fly ash in a high-capacity production of building materials, including cement, concrete, bricks, etc. Due to this reason there is a necessity to develop alternative research technologies where can fly ash will be also used. The purpose of this work is studying the applicability of ash and slag wastes of Kazakhstan thermal power plants as filler for polymer matrix based on polyethylene terephthalate (PET).

\section{Experiment}

Coal energy is predominating in the Republic of Kazakhstan with the share of about $70 \%$ in the general energy balance of the country [18]. Power plants in Kazakhstan work with the coals of different deposits but one of the most common is the coal from the Ekibastuz deposit [18]. It was noted that the technological scheme of coal combustion at thermal power plants in Kazakhstan is based on the traditional scheme of joint slag removal when combustion products, ash and slag, discharged by water through common channels and stored in one slag dump.

The description of fly ash from Ekibastuz coals are given in monographs $[19,20]$ but the absence of references to later literature sources was served as the basis for further carrying out chemical and grain size analysis of the ash composition. The results of the analysis are presented in Table 1 [21].

The fly ash (up to 95\%) consists of oxides of silicon, aluminum, and iron (Table 1) represented by quartz, mullite, and hematite. The content of oxides of alkali and alkaline earth metals in total is $2,3 \%$, and the amount of carbon is more than $3 \%$. In accordance with the standard [22], the ash material with low carbon content (less than 1\%) is classified in class $\mathrm{F}$ and

Table 1 - Data of the phase composition of fly ash from Ekibastuz deposit coal

\begin{tabular}{cccccccccccc}
\hline $\mathrm{SiO}_{2}$ & $\mathrm{Al}_{2} \mathrm{O}_{3}$ & $\mathrm{Fe}_{2} \mathrm{O}_{3}$ & $\mathrm{CaO}$ & $\mathrm{MgO}$ & $\mathrm{TiO}_{2}$ & $\mathrm{~K}_{2} \mathrm{O}$ & $\mathrm{Na}_{2} \mathrm{O}$ & $\mathrm{P}_{2} \mathrm{O}_{5}$ & $\mathrm{MnO}_{2}$ & $\mathrm{SO}_{3}$ & $\mathrm{LOI}$ \\
\hline 61,5 & 27,4 & 5,65 & 1,17 & 0,49 & 1,49 & 0,42 & 0,32 & 0,52 & 0,17 & 0,57 & 5,1 \\
\hline
\end{tabular}


recommended as filler for concretes which are resistant to the impact of sulfate solutions and groundwater [23]. From the results of the grain sizes' analysis of the initial material, it follows that the largest number of particles (more than 60\%) belongs to the class $0.25-0.1 \mathrm{~mm}$. The total amount of other particle sizes is about $40 \%$ or about $10 \%$ of each class (Figure 1), which indicates the possibility of direct ash processing in the mills-activators without the stage of preliminary crushing.

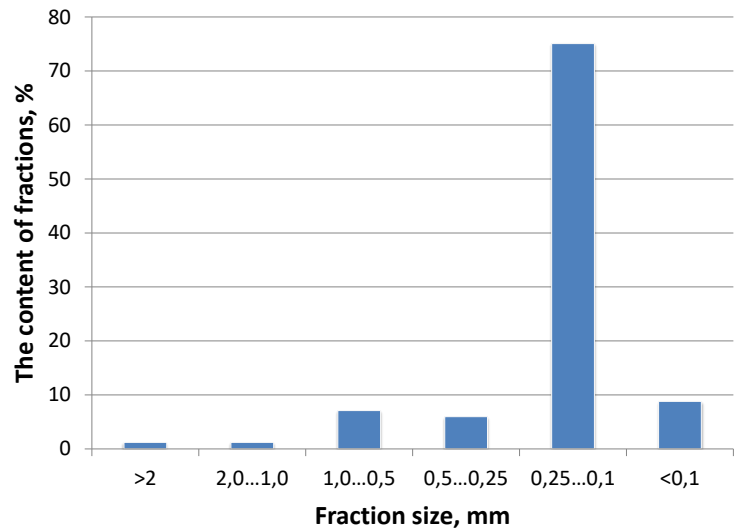

Figure 1 - The diagram of granulometric composition of ash from Ekibastuz deposit coal

Mechanical treatment of ash was carried out in centrifugal mill "Activator 2SL" (Russia) with the closest modes of obtaining the fillers at industrial conditions (in contrast to [24]): the activation time were 5,10 and $15 \mathrm{~min}$; the ratio of the material mass to the grinding bodies mass was $1: 2$ and 1:4; rotated speed of the drums mill was $400 \mathrm{rpm}$. Measurement of the specific surface area before and after mechanical activation was performed by BET method at the analyzer Sorbtometr-M (Russia). The scanning electron microscopy (SEM) was carried out in order to investigate the morphology of the samples surface before and after mechanical treatment using the scanning electron microscope Quanta 3D 200i Dual system, FEI.

Determination of carbon in fly ash material was carried out by means of Raman spectroscopy using Solver Spectrum device with $473 \mathrm{~nm}$ wavelength. Differential thermal analysis of samples was carried out in order to study the phase transformations using analyzer NEITZSCH STA 449 F3Jupiter, in the temperature intervals up 20 to $1000^{\circ} \mathrm{C}$, with a heating rate of $20^{\circ} \mathrm{C}$ per a min. Polarizing microscopy was carried out in order to study the behavior of fly ash filler in the polymer matrix using the microscope Axio VERT1 with optical magnification $\mathrm{x} 100$ and $\mathrm{x} 200$. In addition, a series of tests for obtaining the composite material of the following composition were conducted: PET, hardener (Butanox) and fly ash filler. The mass ratio of mixture $M$ (PET): $M$ (fly ash) was $1: 1$. The polymer material was poured into special forms of $2 \times 2 \times 2 \mathrm{~cm}$ size, with subsequent vibratory compaction of the mixture. The drying process of the samples was implemented at room temperature for $10-12 \mathrm{~h}$.

\section{Results and Discussion}

Nowadays, targeted improvement of the tribological properties of polymers that combine excellent mechanical and chemical resistant properties remains a major problem. Effective management of these properties is achieved by introducing into a polymer matrix of micro- and nanometer sized fillers. However, expensive methods of synthesis of nanodisperse-sized fillers require a search of alternative technological solutions. The most acceptable from a technical and economic point of view is the technology of mechanical activation. Therefore, for averaging of particle size and increasing their reaction activity, mechanical treatment of the fly-ash in a ball mill of planetary type was conducted, which allows providing uniform distribution of filler particles in the volume of the binding agent.

After mechanical fly ash processing a large part of the studied samples had the particle size of 5-15 microns. Larger particles have almost never occurred. The decrease in particle size accompanied by an increase in the specific surface area from $1.3 \mathrm{~m}^{2} / \mathrm{g}$ to $3.6 \mathrm{~m}^{2} / \mathrm{g}$.

The sizes of particles first influence the bulk density of fly ash, and, therefore, the bulk density of mixture which contains the ash. After mechanical treatment with different mass ratios of the milled materials to the grinding bodies, the dispersity of the particles increases and bulk density decreases for $15 \%$. The values of the bulk density of the fly-ash before and after mechanical activation are shown in Table 2.

Table 2 - Specific bulk density of fly ash

\begin{tabular}{cc}
\hline Fly ash & Bulk density $\mathrm{g} / \mathrm{cm}^{3}$ \\
\hline Activated $(1: 2,5 \mathrm{~min})$ & 0.593 \\
Activated $(1: 2,10 \mathrm{~min})$ & 0.581 \\
Activated $(1: 2,15 \mathrm{~min})$ & 0.573 \\
Activated $(1: 4,5 \mathrm{~min})$ & 0.568 \\
Activated $(1: 4,10 \mathrm{~min})$ & 0.561 \\
Activated (1:4, $15 \mathrm{~min})$ & 0.557 \\
Non-activated & 0.657
\end{tabular}

It was found that the best characteristics were demonstrated by the samples of polymers with filler obtained at the 15-minute mode of mechanical treatment when the mass ratio of ash to the mass of balls was equal to $1: 4$. We used this activation mode in our subsequent experiments.

The studied fly ash contained a large number of the microspheres' inclusions (Figure 2). However, after grinding the 
(a)

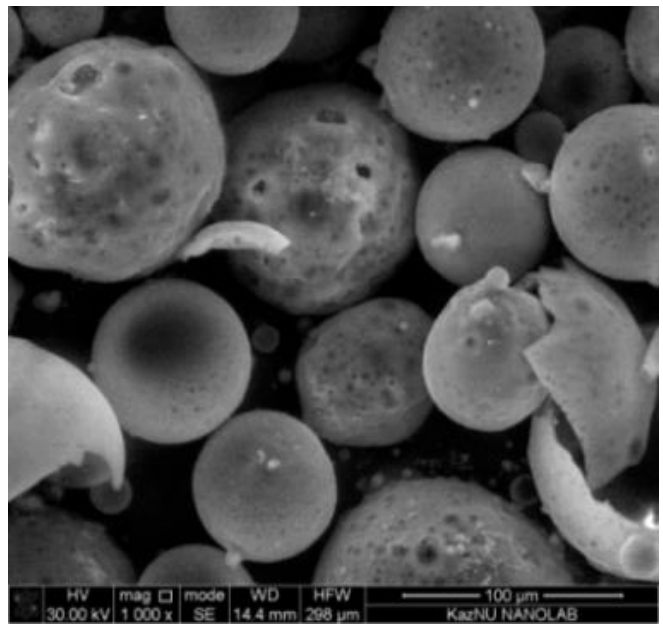

(b)

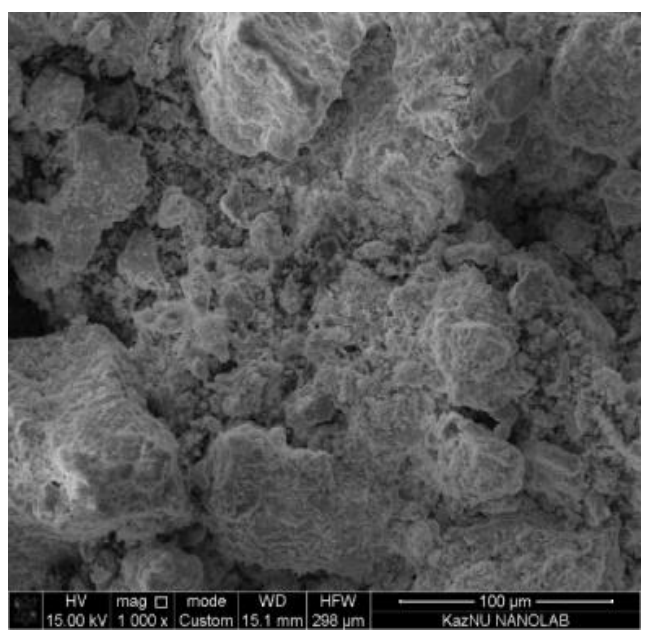

Figure 2 - SEM-analysis of fly ash: a) before mechanical activation; b) after mechanical activation

(a)

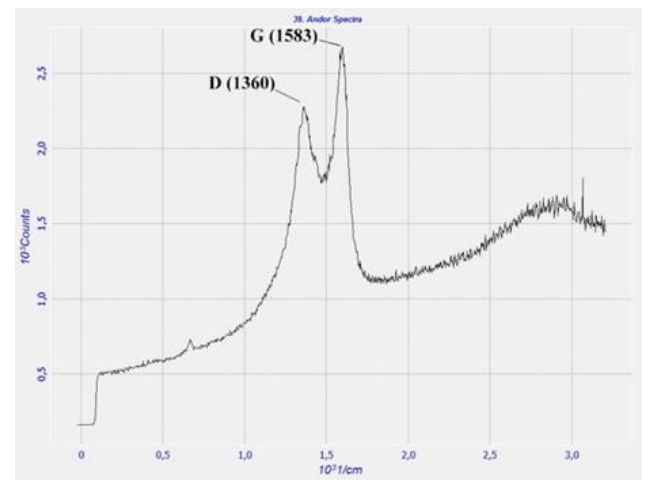

(b)

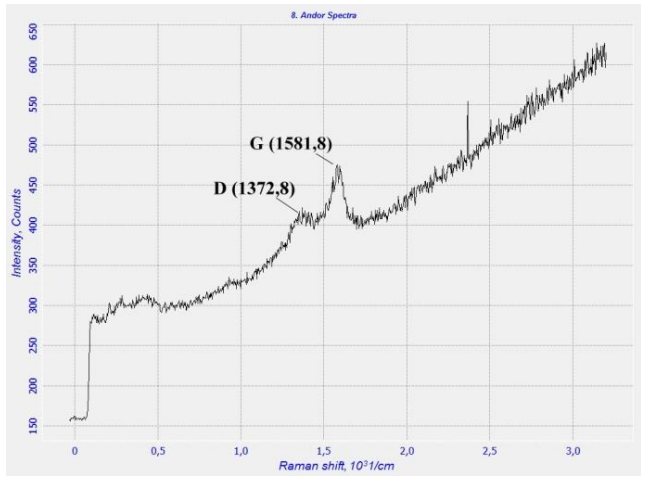

Figure 3 - Raman spectroscopy of fly ash before (a) and after mechanical activation (b)

particles of microspheres got a fragmentary rough particle form with a loose structure of surface due to covering the surface with carbon in the mechanical activation process.

The structure of pointed duplet peaks of the Raman spectra is shown at Figure $3(a, b)$. It demonstrates the characteristic peaks of crystalline carbon at D $1360 \mathrm{~cm}^{-1}$ and $G$ $1583 \mathrm{~cm}^{-1}$ wavelengths that correspond to graphite. However, in a greater degree the peak at $1360 \mathrm{~cm}^{-1}$ can be associated with a defect of the carbon structure resulting from temperature drop during ash cooling. The results of Raman spectroscopy of crushed filler demonstrated the shift of peaks $G$ and $D$ carbon in the low-frequency area with broadening the peaks indicating uniform distribution of carbon. Sloping peaks D $1372.8 \mathrm{~cm}^{-1}$ and for $\mathrm{G} 1581.8 \mathrm{~cm}^{-1}$ (Figure $3 \mathrm{~b}$ ) indicate the distribution of carbon across the surface of the sample.

The carbon presence on the sample surfaces after mechanical treatment was proved by the change of the contact angle of wetting in aqueous solutions; the definition of which was carried out by the method described in [24]. It is seen from the results of measurements that before mechanical activation the contact angle was $\theta=41^{\circ}$, and after mechanical treatment it became $\theta=29^{\circ}$. The change in contact angle downward indicates increase in hydrophilicity of the powder material, which can be explained only by the presence of carbon on the surface of the particles.

The view of curves of differential thermal analysis for nonactivated and activated samples (Figure $4 \mathrm{a}$, and b) has a complex form characterized by the occurrence of parallel processes. In the low-temperature area up to $200^{\circ} \mathrm{C}$ competing reactions are taking place: the losses of adsorbed water from the ash particles, and the start of carbon oxidation. For non-activated fly ash sample, the mass loss was about $2.2 \%$. At the same time for the samples subjected to mechanical impact mass loss in this temperature interval was negligible. It was due to the fact that the process of mechanical reduction of particle size was accompanied by increase of temperature of particles over than $100^{\circ} \mathrm{C}$ that led to the loss of adsorbed water. 


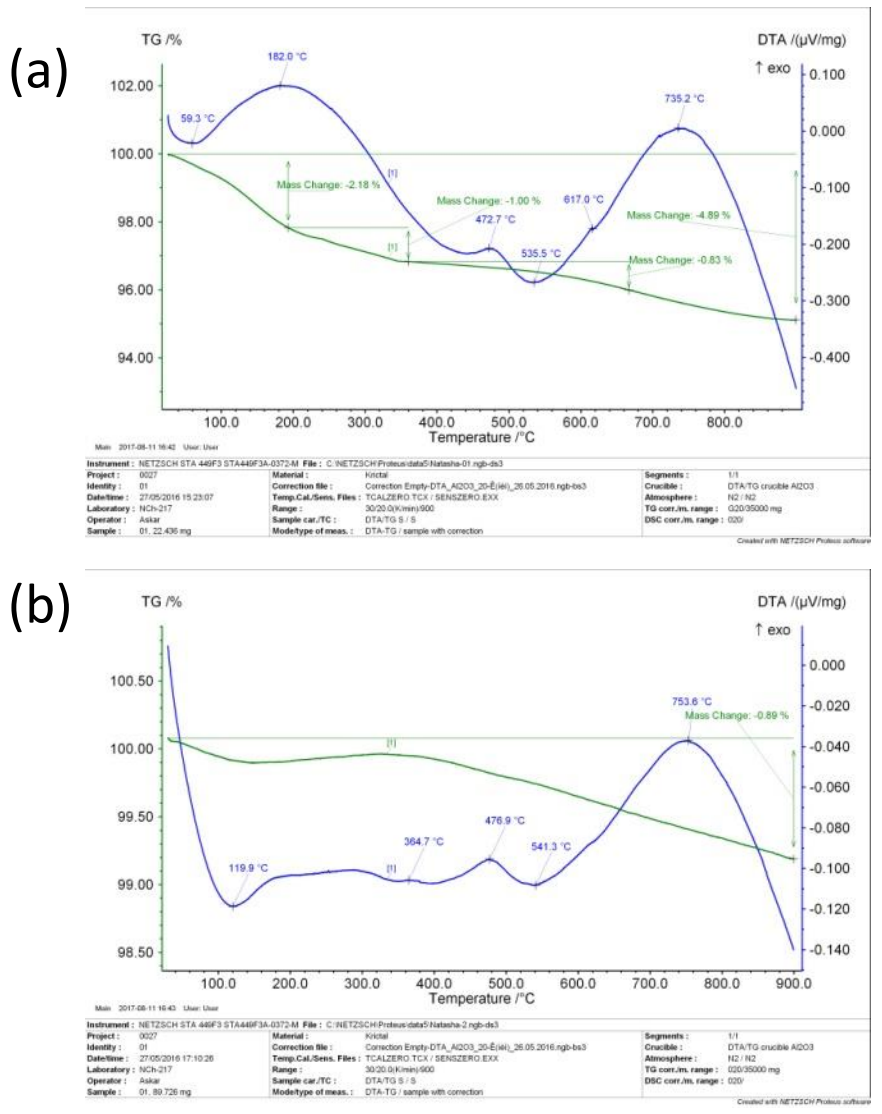

Figure 4 - DTA analysis of fly-ash: a) before mechanical activation; b) after mechanical activation

On the DTA curve of the mechanically activated samples Figure $4 \mathrm{~b}$ is noted intensive process of oxidation of the coal part of fly ash from $400^{\circ} \mathrm{C}$, while for non-activated sample the peak was shifted to $430^{\circ} \mathrm{C}$ with the end of the process of oxidation for both simples at temperatures above $500^{\circ} \mathrm{C}$. Exothermic effects in the temperature interval $735-750^{\circ} \mathrm{C}$ can be associated with the transformation of quartzite into tridymite and the inevitable changes that occur in the glass phase of the ash under the heat. In addition, the sintering process can result to additional broadening the lines of the curve of differential thermal analysis.

Generally, the use of fly ash as filler for composite materials based on cement is limited by the presence of unburned carbon in the composition of the fly ash. However, for polymer compositions carbon presence is not a critical feature. It is known that under mechanical mixing the polymer with the filler (carbon black) polymer radicals interact with the active sites of the filler particles forming the chemical bond 'polymer-filler'. When elastomers are mixed with carbon black there is formed a gel-like structure where the elastomer is chemically associated with the filler [25-29]. The phenomena of hardening the elastomers by carbon black were discovered as far back as 1912 and are actively explored to this day. In general, the mechanism of the phenomenon of strengthening the polymer durability is determined by a set of geometrical, physical and chemical properties of carbon $[27,28]$. In fact, it occurs as a result of ordering the macromolecules that related to each other.

Therefore, with the aim of establishing the interaction between the fly ash filler and binding agent polarizing microscopy at optical magnification $\times 100$ and $\times 200$ was carried out. As it is seen from Figure 5 ( $a$ and $b$ ), the sample from the non-activated material presents a heterogeneous system of solid and liquid phases with an accurately defined interface. The samples filled with a mechanical activated fly ash material (Figure $5 \mathrm{c}$, d) with carbon on its surface represents a homogeneous system, indicating the interaction between the polymer matrix and carbon.

Measurement of properties of the polymer composition was carried out in accordance with the standards [30-33] and the results are presented in Table 3.

According to the obtained data (Table 3 ) it was found that the strength of polymer compositions was collected within 14 days and then remained almost unchanged. For samples with mechanically activated filler the maximum value of the strength in compression was $1.1 \mathrm{MPa}$; for non-activated ash powders the strength value was $0.4 \mathrm{MPa}$.

Thus, polymer materials based on mechanically activated fillers demonstrated better strength values that can be 
(a)

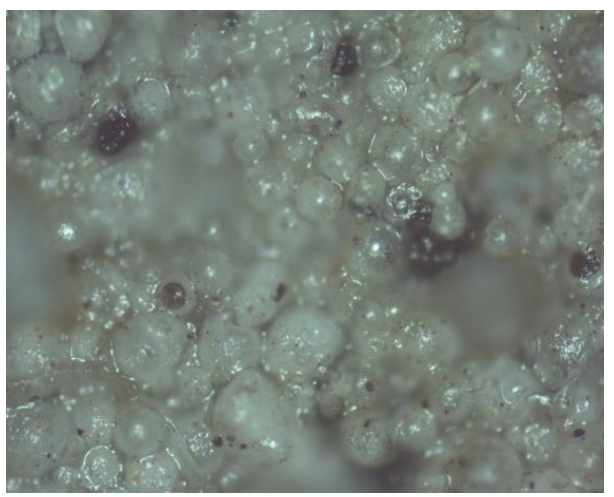

(c)

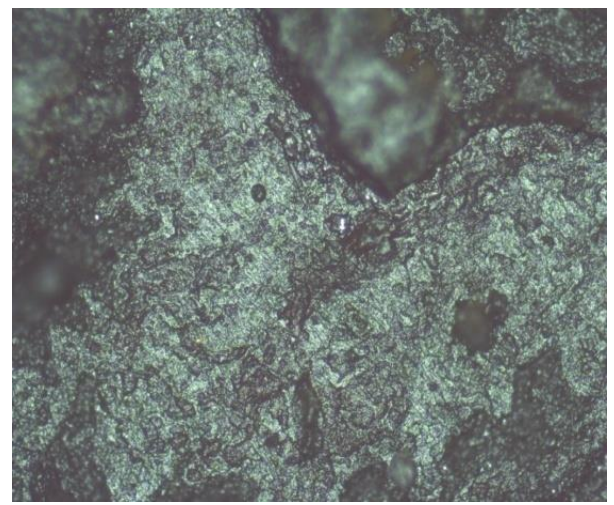

(b)

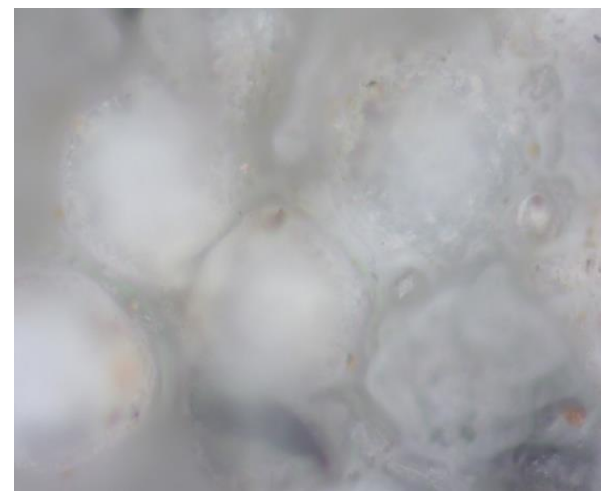

(d)

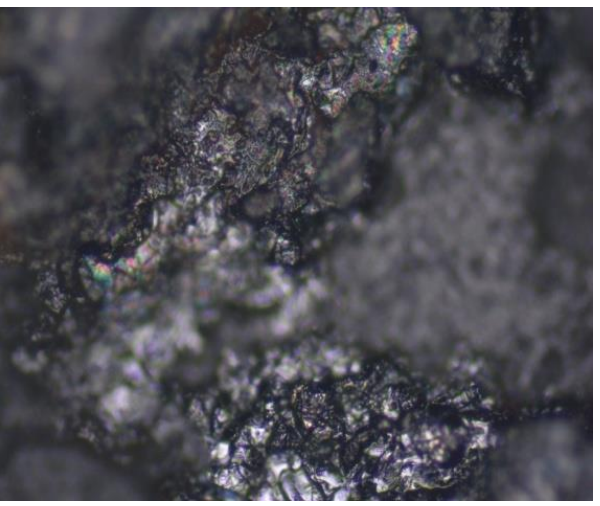

Figure 5 - Polarizing microscopy of polymer composite material filled with ash material: a) non-activated ( $\times 100)$; b) non-activated $(\times 200)$; c) activated $(\times 100)$; d) activated $(\times 200)$

Table 3 - Measured properties of the polymer composition

\begin{tabular}{ccc}
\hline Strength characteristics & Non-activated filler & Mechanical activated filler \\
\hline Strength in compression at $14^{\text {th }}$ day, $\mathrm{MPa}^{*}$ & 0.4 & 1.1 \\
Water absorption, \% $^{* *}$ & 0.5 & 0.1 \\
Acid resistance, \%** & 96 & 97 \\
\hline
\end{tabular}

*The strength in compression of the samples was determined on a hydraulic press Cyber-Plus Evolution Mod YIMC109NC.

$* *$ When determining the water absorption of the samples, the exposition time was conventionally equal to $24 \mathrm{~h}$.

*** When determining the acid resistance of the samples, the exposition time was conventionally equal to $24 \mathrm{~h}$. Two acids were used: sulfuric and nitric acid, with concentration of $34 \%$.

associated not only with the better distribution of the filler in the polymer matrix but with the additional interaction of the components of the composite mixture.

Water absorption of all samples regardless of the type of filler was almost always equal to zero. The reason was because most polyesters are resistant to water.

Acid resistance of all samples was 96-97\%, which corresponds to the established norms of standards.

\section{Conclusions}

During this research the effect of preliminary mechanical activation on fly ash properties of Almaty Thermal power plant-2, as well as the possibility of its use as fillers for polymers, was studied.

The role of carbon in the formation of the ordered structure of a polymer composite material was shown, and it resulted to the greater mechanical strength of samples with mechanically activated fly ash filler.

\section{Acknowledgements}

This work was conducted under the project 3474/GF funded by the Ministry of Education and Science of Kazakhstan. 


\section{References (GOST)}

1 Vincent S.R., Jaafar M., Palaniandy S. Properties of calcium carbonate/mica and calcium carbonate/talc filled polypropylene composites // Journal of Engineering Science. - 2014. - Vol.10. - P.41-47.

2 Cardone F., Frigio F., Ferroti G., Canestrari F. Influence of mineral fillers on the rheological response of polymer-modified bitumens and mastics // Journal of Traffic and Transportation Engineering (English Edition). - 2015. - Vol.2, Is.6. - P.373-381.

3 Intharapat P., Kongnoo A., Kateungngan K. The potential of chicken eggshell waste as a bio-filler filled epoxidized natural rubber (ENR) composite and its properties // Journal of Polymers and the Environment. - 2013. - Vol.21. - P.245-258.

4 Sivarao, Vijayaram T.R. Determination of tensile, flexural properties and microstructural characterization of calcium carbonate filler reinforced polypropylene matrix composites // Transactions of the Indian Institute of Metals. - 2009. - Vol.62, Is.3. - P.245-248. 5 Thenepalli T., Jun A.Y., Han Ch., Ramakrishna Ch., Ahn J.W. (2015) A strategy of precipitated calcium carbonate $\left(\mathrm{CaCO}_{3}\right)$ fillers for enhancing the mechanical properties of polypropylene polymers // Korean Journal of Chemical Engineering. - 2015. - Vol.32, Is.6. - P.1009-1022.

6 Abdullah A.H., Rusel D.S., Abdulwahab A.S. Water absorption and mechanical properties of high - density polyethylene/egg shell composite // Journal of Basrah Researches (Sciences). - 2011. - Vol.37, Is.3A. -P.36-42.

7 Prashanth S.J., Arun K.V., Satish K.G. Behavior of coconut shell powder filled polymer composites under impact and bending loads // International Journal of Engineering and Computer Science. - 2017. - Vol.6, Is.8. - P.2582-2585.

8 Vignesh K.,Sivakumar K., Prakash M. et al. Experimental analysis of mechanical properties of alkaline treated coconut shell powder - polymer matrix composites // International Journal of Advanced Engineering. - 2015. - Vol.1, Is.4. - P.448-453.

9 Shakuntala Ojha, Raghavendra G., Acharya S.K. A comparative investigation of bio waste filler (wood apple-coconut) reinforced polymer composites // Polymer Composites. - 2013. - Vol.35, Is.1. - P.180-185.

10 Li H.Y., Tan Y.Q., Zhang L., Zhang Y.X. et al. Bio-filler from waste shellfish shell: preparation, characterization, and its effect on the mechanical properties on polypropylene composites // Journal of Hazardous Materials. - 2012. -Vol.217-218. - P.256-262.

11 Spathi Ch., Vandeperre L.J., Cheeseman C.R. Production of lightweight fillers from waste glass and paper sludge ash // Waste and Biomass Valorization. - 2015. - Vol.6. - P.875-881.

12 Swaminathan G., Rajendra Prasad A., Suresh S.M., Vignesh C. Experimental analysis of hardness and densification of microwave sintered $\mathrm{AL} / \mathrm{SIC} / \mathrm{Al}_{2} \mathrm{O}_{3} /$ fly ash composites // Indian Journal of Science and Technology. - 2016. - Vol.9, Is.42. - P.1-6.

13 Silva P., de Brito J. Electrical resistivity and capillarity of self-compacting concretewith incorporation of fly ash and limestone filler // Advances in Concrete Construction. - 2013. - Vol.1, Is.1. - P.65-84.

14 Huang X., Hwang J.Y., Gillis J.M. (2003) Processed low NO fly ash as a filler in plastics // Journal of Minerals \& Materials Characterization \& Engineering. - 2003. - Vol.2, Is.1. - P.11-31.

15 Raposeiro da Silva P, de Brito J Durability performance of self-compacting concrete (SCC) with binary and ternary mixes of fly ash and limestone filler // Materials and Structures. - 2016. - Vol.49. - P.2749-2766.

16 Mistrya R., Roy T.K. Effect of using fly ash as alternative filler in hot mix asphalt // Perspectives in Science. - 2016. - Vol.8. P.307-309.

17 Бурдонов А.Е., Барахтенко В.В., Зелинская Е.В., Сутурина Е.О., Бурдунова А.В., Головнина А.В. Физико-механические характеристики композиционных материалов на основе отходов производства с различными рецептурами // Инженерностроительный журнал. - 2012. - №9. - С.14-22.

18 Каренов Р.С. Актуальность внедренияновыхэкологическичистыхиэкономически выгодныхтехнологий использования углей // Вестник КаргУ. - 2012. - №1(65). - С.50-56.

19 Кизильштейн Л.Я., Дубов И.В., Шпицглуз А.Л., Парада С.Г. Компоненты зол и шлаков ТЭС. - М.: Энергоатомиздат, 1995. $-176 \mathrm{c}$.

20 Зырянов В.В., Зырянов Д.В. Зола уноса - техногенное сырье. - М.: ООО «ИПЦ «Маска»», 2009. - 320 с.

21 Андреева Л.Н., Борбат В.Ф. Зола ТЭЦ перспективное сырье для промышленности // Вестник Омского университета. 2009. - №2. - С.141-151.

22 ASTM C 618-05 Standard specification for coal fly ash and raw or calcined pozzolan for use as a mineral admixture in concrete, ASTM Int - Testing method. - ASTM International, United States, 2005.

23 Fly-ash for concrete. Accessed 28 August 2017.

24 Киселев М.Г., Савич В.В., Павич Т.П. Определение краевого угла смачивания на плоских поверхностях // Наука и техника. - 2006. - №1. - С.38-41.

25 Стрижак Е.А. Исследование однородности резин с моно- и бинарными композициями наноструктурированного углеродного наполнителя: дисс. .. канд. хим. наук: 05.17.06: защищена 25.02.2010: утв. 20.08.2010 /. - М.: ГТУ им. А.Н. Косыгина 2010. -163 с.

26 Dupres S., Long D.R., .Sotta P., Albouy P. Local Deformation in Carbon Black-Filled Polyisoprene Rubbers Studied by NMR and X-ray Diffraction // Macromolecules. - 2009. - Vol.42, Is.7. - P.2634-2644. 
27 Лыкин А.С. Резины, наполненные техническим углеродом // Вопросы практической технологии изготовления шин. 2009. - №5. - С.9.

28 Киселёва Е.А. Исследование взаимодействия эластомеров с углеродными наполнителями различной дисперсности и структуры: дисс. ... канд. хим. наук: 05.17.06; 02.00.11: защищена 08.12.2011: утв. 20.07.2012 /. - М.: ГТУ им. А.Н. Косыгина 2011. -157 c.

29 Кохановская О.А. Изучение влияния морфологии и физико-химических свойств дисперсного углерода на процесс образования наполненных гелевых матриц на основе водорастворимых полимеров структуры: дисс. ... канд. хим. наук: 02.00.04: защищена 17.04.2012: утв. 22.11.2012 /. - Омск.: ОмГТУ 2012. - 201 с.

30 EN ISO 10545. Appendix 1. EN ISO norms for ceramic tiles - Testing methods.

31 ГОСТ 8462-85. Методы определения пределов прочности при сжатии и изгибе. Государственный стандарт союза ССР, утвержден и введен в действие 1985-01-18. - М.: Издательство стандартов, 1987.

32 ГОСТ 12730.3-78 Бетоны. Метод определения водопоглощения. Утвержден и введен в действие Постановлением Государственного комитета СССР по делам строительства от 22.12.78 N 242. - М.: Стандартинформ, 2007.

33 ГОСТ 473.1-81 Изделия химически стойкие и термостойкие керамические. Метод определения кислотостойкости. Утвержден и введен в действие Постановлением Государственного комитета СССР по стандартам от 22 июня 1981 г. N 3035. - М.: Издательство стандартов, 1981.

\section{References}

1 Vincent SR, Jaafar M, Palaniandy S (2014) Journal of Engineering Science 10:41-47.

2 Cardone F, Frigio F, Ferroti G, Canestrari F (2015) J Traffic Transp Eng (English Edition) 2(6):373-381. https://doi.org/10.1016/j. jtte.2015.06.003

3 Intharapat P, Kongnoo A, Kateungngan K (2013) J Polym Environ 21:245-258. https://doi.org/10.1007/s10924-012-0475-9

4 Sivarao, Vijayaram TR (2009) Trans Indian Inst Met 62:245-248. https://doi.org/10.1007/s12666-009-0027-8

5 Thenepalli T, Jun AY, Han Ch, Ramakrishna Ch, Ahn JW (2015) Korean J Chem Eng 32(6):1009-1022. https://doi.org/10.1007/ s11814-015-0057-3

6 Abdullah A.H., Rusel D.S., Abdulwahab A.S. Water absorption and mechanical properties of high - density polyethylene/egg shell composite // Journal of Basrah Researches (Sciences). - 2011. - Vol.37, Is.3A. -P.36-42.

7 Prashanth SJ, Arun KV, Satish KG (2017) International Journal of Engineering and Computer Science 6(8):2582-2585.

8 Vignesh K, Sivakumar K, Prakash M et al (2015) International Journal of Advanced Engineering 1(4):448-453.

9 Shakuntala Ojha, Raghavendra G, Acharya SK (2014) Polym Compos 35(1):180-185. https://doi.org/10.1002/pc.22648

10 Li HY, Tan YQ, Zhang L, Zhang YX et al (2012) J Hazard Mater 217-218:256-262. https://doi.org/10.1016/j.jhazmat.2012.03.028

11 Spathi Ch, Vandeperre LJ, Cheeseman CR (2015) Waste Biomass Valor 6:875-881. https://doi.org/10.1007/s12649-015-9370-7

12 Swaminathan G, Rajendra Prasad A, Suresh SM, Vignesh C (2016) Indian J SciTechnol 9(42):1-6. https://doi.org/10.17485/ ijst/2016/v9i42/103308

13 Silva P, de Brito J (2013) Adv Concr Constr 1(1):65-84. http://doi.org/10.12989/acc.2013.1.1.065

14 Huang X, Hwang JY, Gillis JM (2003) J Miner Mater Charact\& Eng 2(1):11-31.

15 Raposeiro da Silva P, de Brito J (2016) Mater Struct 49:2749-2766. https://doi.org/10.1617/s11527-015-0683-6

16 Mistrya R, Roy TK (2016) Perspect Sci 8:307-309. https://doi.org/10.1016/j.pisc.2016.04.061

17 Burdonov AE, Barachtenko VV, Zelinskaya EV, Suturina EO, Burdonova AV, Golovnina AV (2012) Magazine of Civil Engineering 9:14-22. (In Russian). http://doi.org/10.5862/MCE.35.2

18 Karenov RS (2012) Bulletin of KarSU [Vestnik KarGU] 1(65):50-56. (In Russian)

19 Kizilshtein LYa, Dubov IV, Shpincgluz AL, Parada SG (1995 Constituents of the heat power stations ashes and slags [Komponenty zol i shlakov TES]. Energoatomizdat, Moscow, Russia. (In Russian)

20 Zyryanov VV, Zyryanov DV (2009) Fly ash - technogenic raw material [Zola unosa - tekhnogennoye syr'ye]. IIC "Maska", Moscow, Russia. (In Russian)

21 Andreyena LN, Borbat VF (2009) Bulletin of Omsk University [Vestnik Omskogo universiteta] 2:141-151. (In Russian)

22 (2005) ASTM C 618-05 Standard specification for coal fly ash and raw or calcined pozzolan for use as a mineral admixture in concrete, ASTM Int - Testing method.

23 (2014) Fly-ash for concrete. Accessed 28 August 2017.

24 Kisilev MG, Savich VV, Pavich TP (2006) Science and technique [Nauka i tehnika] 1:38-41. (In Russian)

25 Strizhak EA (2010) The study of the homogeneity of rubbers with mono- and binary compositions of nanostructured carbon filler [Issledovaniye odnorodnosti rezin s mono- i binarnymi kompozitsiyami nanostrukturirovannogo uglerodnogo napolnitelya]. Dissertation for the degree of candidate of chemical sciences, Russian Correspondence Institute of Textile and Light Industry, Moscow, Russia. (In Russian) 
26 Dupres S, Long DR, .SottaP, Albouy P (2009) Macromolecules 42(7):2634-2644. http://doi.org/10.1021/ma900006y

27 Lykin AS (2009) Questions practical tire manufacturing technology [Voprosy prakticheskoy tekhnologii izgotovleniya shin] 5:9. (In Russian)

28 Kiseleva EA (2011) Investigation of the interaction of elastomers with carbon fillers of various dispersity and structure [Issledovaniye vzaimodeystviya elastomerov s uglerodnymi napolnitelyami razlichnoy dispersnosti i struktur]. Dissertation for the degree of candidate of chemical sciences, AN Kosygin GTU, Moscow, Russia.

29 Kokhanovskaya OA (2012) Study of the effect of the morphology and physicochemical properties of dispersed carbon on the formation of filled gel matrices based on water-soluble polymers of the structure [Izucheniye vliyaniya morfologii $i$ fizikokhimicheskikh svoystv dispersnogo ugleroda na protsess obrazovaniya napolnennykh gelevykh matrits na osnove vodorastvorimykh polimerov struktury]. Dissertation for the degree of candidate of chemical sciences, Omsk STU, Omsk, Russia.

30 EN ISO 10545. Appendix 1. EN ISO norms for ceramic tiles - Testing methods.

31 GOST 8462-85. Wall materials. Methods for determination of ultimate compressive and bending strength. Approved and enacted 1985-01-18. Publishing house of standards, Moscow, USSR.

32 GOST 12730.3-78 Concretes. Method of determination of water absorption. Approved and enacted by the Decree of the USSR State Committee for Construction Affairs of 12/22/78 N 242. Standartinform, Moscow, Russia, 2007.

33 GOST 473.1-81 Chemically resistant and heat resistant ceramic wears. The method for determination of acid resistance. Approved and enacted by the Resolution of the State Committee of the USSR on Standards of June 22, $1981 \mathrm{~N} 3035$. Standards Publishing House, Moscow, USSR. 